\title{
STUDENT'S COMPARATIVE ANALYSIS TOWARDS THE TEACHING-LEARNING SYSTEM THROUGH E-LEARNING
}

\author{
Ersan Suria Pranoto' ${ }^{1}$ Haryadi Sarjono ${ }^{2}$ \\ ${ }^{1}$ Jurusan Hotel Management, Fakultas Ekonomi dan Bisnis, Bina Nusantara University \\ Jln. K.H. Syahdan No. 9, Kemanggisan, Palmerah, Jakarta Barat 11480 \\ 2 Jurusan Manajemen, Fakultas Ekonomi dan Bisnis, Bina Nusantara University \\ Jln. K.H. Syahdan No. 9, Kemanggisan, Palmerah, Jakarta Barat 11480
}

\begin{abstract}
The purpose of this study was to measure the student response in comparison between Management Department and Accounting Department at the Faculty of Economics, University of Bunda Mulia, against a system of learning in the e-learning system based. The samples are taken by using non-probability sampling method that is very much purposive. The amount of data to be collected as many as 300 students (respondents) conducted in a proportion as of for the Accounting Department samples of 150 respondents were taken and from the Department of Management also 150 respondents were taken, with a standard error in around 1\%. The amount of data is adjusted to the time of data collection conducted during the months of March to May 2008, this was also during the lectures take place in the second semester of 2007/2008. For the idea of applying the elearning system based, the result in the major of accounting, which are 76\%, said that the idea seems to be right if e-Learning is applied but for the Department of Management students, only 32\% of students who was responded quite well.
\end{abstract}

Keywords: forward contract, CPO, KLSE, cyclic forecasting, simulation, back-testing

\begin{abstract}
ABSTRAK
Minyak sawit mentah (CPO) merupakan salah satu komoditas yang selain dapat dikonsumsi, juga sebagai salah satu alternatif bahan bakar non-fosil yaitu biodiesel. Sejak tahun 2006, perdagangan komoditas CPO mengalami peningkatan signifikan, yang diikuti dengan peningkatan perdagangan kontrak berjangkanya. Pertumbuhan harga CPO tahun 2006 adalah yang terendah yang membuat periode analisis data historis yang digunakan adalah periode 2007-2008. Model cyclic forecasting yang digunakan mengikuti pola siklus dua tahunan, dengan kombinasi fungsi Solver dalam Ms Excel dapat meminimalisasi MSE menjadi 161,02, dengan Beta 0,0688 dan intercept sebesar -11,0396. Cyclic forecasting sebaiknya digunakan bersamaan dengan analisis teknikal, selalu gunakan stop loss untuk mengurangi risiko. Diperlukan penelitian tambahan untuk menyesuaikan confidence level agar nilai VaR tidak terlalu besar, sehingga dapat memperbaiki keandalan trading strategy yang telah digunakan dalam penelitian ini.
\end{abstract}

Kata kunci: kontrak berjangka, CPO, KLSE, cyclic forecasting, simulasi, back-testing 


\section{PENDAHULUAN}

\section{Latar Belakang}

Penggunaan biodiesel sebagai bahan bakar alternatif merupakan salah satu jawaban atas permasalahan semakin menipisnya cadangan minyak bumi dunia. Kelapa sawit mentah atau crude palm oil (selanjutnya disingkat CPO) adalah salah satu produk biodiesel yang paling diminati oleh industri dunia. Malaysia dan Indonesia merupakan produsen dan pengekspor komoditas CPO terbesar di dunia (sebesar 85\%), dengan negara-negara tujuannya antara lain: Amerika, Eropa, India, serta China. Perkembangan perdagangan komoditas CPO sendiri mengalami peningkatan yang signifikan dari tahun ke tahun, yang diikuti dengan perdagangan kontrak berjangka CPO (selanjutnya disebut FCPO).

Sejatinya, kontrak berjangka suatu komoditas digunakan untuk melakukan lindung-nilai (hedging) atas fluktuasi harga komoditas tersebut di masa depan, tetapi justru lebih dari $90 \%$ kontrak berjangka ditutup oleh pelaku pasar sebelum jatuh tempo (Hull, 2005). Hal tersebut menunjukkan bahwa unsur spekulatif banyak berperan dalam perdagangan kontrak berjangka, termasuk dalam perdagangan FCPO, di mana pelaku pasar digunakannya untuk mencari keuntungan dari hasil spekulasi. Bursa Malaysia sudah menjadi sumber penelitian ini karena volume transaksinya jauh lebih besar daripada Bursa Berjangka Jakarta (BBJ), walaupun Malaysia dan Indonesia merupakan produsen CPO terbesar di dunia, akan tetapi pada praktik perdagangan kontrak berjangka Indonesia masih tertinggal.

Kontrak berjangka CPO yang akan diteliti oleh penulis adalah kontrak berjangka waktu 3 bulan karena menjadi benchmark contract month. Apabila investor membeli atau menjual kontrak berjangka 3 bulan ini, terdapat cukup waktu untuk menyelesaikan atau menutup transaksi kontrak sebelum masa jatuh tempo, sehingga investor spekulan tidak perlu melaksanakan kewajibannya (menerima secara fisik komoditas tersebut), dan juga kontrak bulan ketiga ini mempunyai tingkat likuiditas yang paling tinggi.

Berbeda dengan hedger, para spekulan mengambil keuntungan dari pergerakan fluktuasi harga yang terjadi. Pergerakan harga yang berfluktuasi naik-turun menciptakan pola-polanya tersendiri. Pola-pola pergerakan harga historis ini dapat terlihat dari waktu ke waktu pada grafik. Pola-pola ini mempunyai makna yang dapat diinterpretasikan untuk memprediksi pergerakan harga di masa depan. Di dalam ilmu statistik, pola pergerakan yang berulang dikenal sebagai gerakan siklis (cyclical movement). Di dalam dunia bisnis, metode peramalan siklus (cyclic forecasting) biasa digunakan sebagai indikator bisnis untuk mengidentifikasi peristiwa atau kejadian yang biasa terulang, dalam mengantisipasi gejala-gejala musiman yang dapat terjadi di masa depan. Metode inilah yang digunakan untuk meramalkan harga FCPO di masa mendatang. Penelitian ini bersifat eksperimental, simulasi perdagangan back-testing didukung dengan metode peramalan cyclic forecasting.

\section{Ruang Lingkup}

Ruang lingkup penelitian dibatasi pada data penelitian menggunakan harga kontrak berjangka CPO tahun 2006-2008, simulasi perdagangan berjangka menggunakan kontrak berjangka CPO dengan periode kontrak 3 bulan di Bursa Malaysia (kode FCPO), yang dilakukan pada periode JanuariDesember 2009. Pajak perdagangan tidak termasuk dalam simulasi perdagangan berjangka ini. Analisis dilakukan dari sudut pandang investor Malaysia, yang menggunakan mata uang RM (Ringgit Malaysia), sehingga risiko fluktuasi kurs RM/IDR belum diperhitungkan. 


\section{Tujuan dan Manfaat Penelitian}

Secara spesifik, tujuan penelitian adalah melakukan analisis pergerakan harga kontrak berjangka CPO, peramalan (forecasting) harga kontrak berjangka periode Januari-Desember 2009 dan membuat simulasi backtesting perdagangan berjangka CPO sekaligus mengukur tingkat kinerja dengan Return on Margin (ROM). Beberapa manfaat penelitian yang bisa diberikan adalah menjelaskan pola-pola siklus yang berulang pada pergerakan harga FCPO, untuk menentukan periode siklus yang paling mendekati data aktualnya, menentukan kapan entry atau exit bursa berjangka CPO, berdasarkan hasil peramalan yang didukung dengan VaR sebagai titik Stop Loss (trading policy) dan menganalisis potensi investasi dalam bentuk perdagangan kontrak berjangka CPO, khususnya di KLSE.

\section{METODE}

Sumber data berasal dari situs Bursa Malaysia, yaitu data harian settle price FCPO periode Januari 2006-Januari 2010. Standar deviasi digunakan untuk menentukan tingkat fluktuasi harga dan fluktuasi laba kontrak berjangka bulanan, Mean Squared Error (MSE) untuk mengukur tingkat akurasi cylcic forecasting, hasil peramalan dengan cylcic forecasting,digunakan untuk posisi entry market, sedangkan Value at Risk (VaR) digunakan untuk menentukan stop loss (batas exit market saat harga bergerak di luar kondisi yang diharapkan saat simulasi), Return On Margin (ROM) untuk mengukur tingkat kinerja simulasi. Hasil analisis dan perhitungan data akan disajikan baik dalam bentuk tabel, grafik ataupun bagan. Gambar 1 menjelaskan bagan alur penelitian.

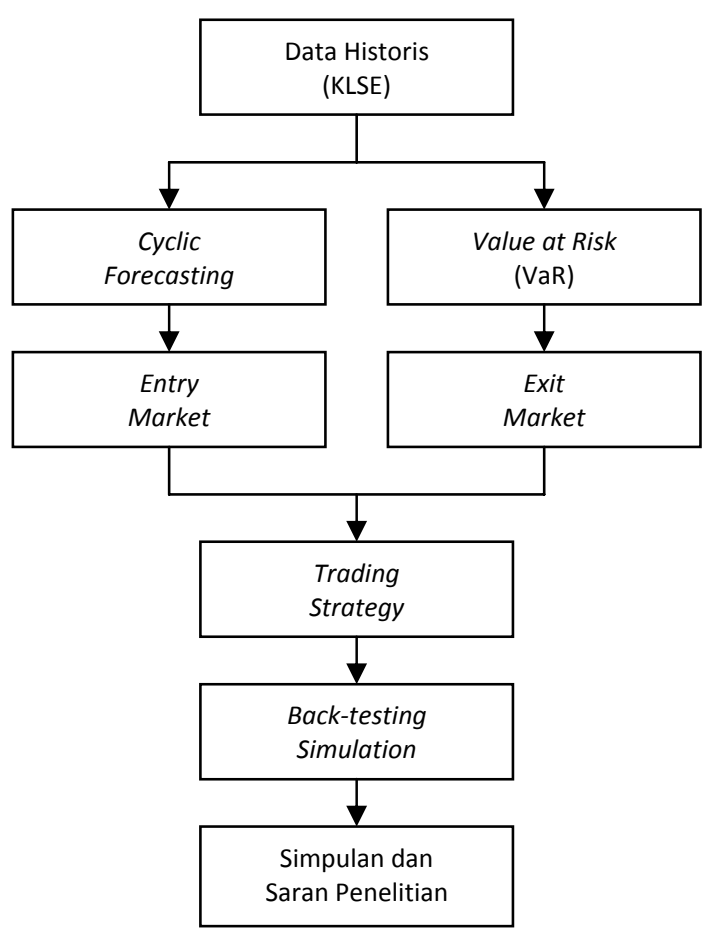

Gambar 1 Bagan alur penelitian 


\section{Tinjauan Teori}

Secara umum Elton, Gruber, Brown, \& Goetzmann (2003) mengelompokkan instrumen keuangan menjadi seperti pada Gambar 2.

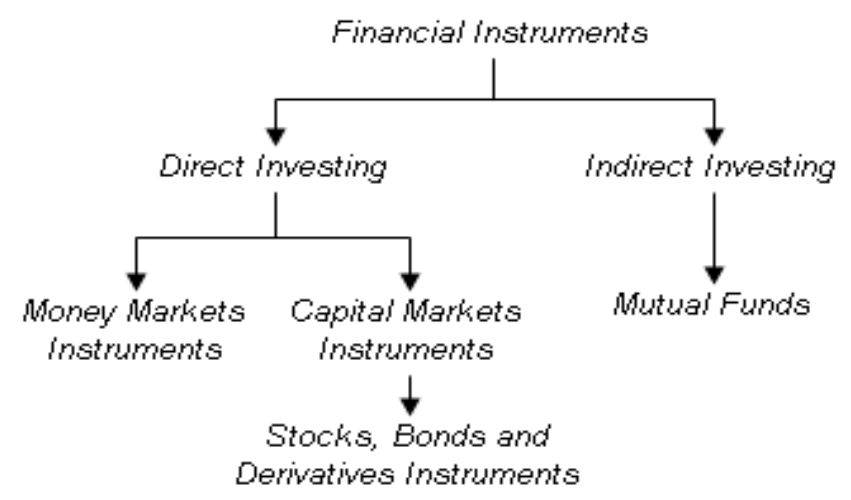

Gambar 2 Kelompok instrumen keuangan

Kontrak berjangka (futures contract) adalah salah satu instrumen turunan (derivatives) yang merupakan bentuk direct investing, dimana harga kontrak berjangka tergantung pada underlying assets, yang jatuh tempo pada periode tertentu (Hull, 2005). Tujuan awal penggunaan kontrak berjangka adalah untuk melakukan hedging, tetapi dalam perkembangannya, instrumen ini lebih cenderung digunakan sebagai salah satu sarana investasi spekulatif, karena lebih dari $90 \%$ pelaku pasar melepas posisi mereka sebelum jatuh tempo.

Menurut Aczel \& Sounderpandian (2002), data-data dengan jangka waktu bulanan atau tahunan melalui sebuah pengamatan biasanya mempunyai variasi gerakan yang berulang dari waktu ke waktu. Dalam dunia bisnis dan ekonomi, terdapat perilaku siklis (berputar atau berulang) yang sering disebut dengan siklus bisnis. Siklus bisnis ini ditandai dengan lembah (trough), bergerak naik (up swing), membentuk puncak (peak), dan kemudian bergerak turun (down swing), dari aktivitas bisnis dalam suatu perputaran siklus yang berlangsung dalam beberapa tahun. Siklus ini sering tidak menentu, polanya sulit untuk ditebak, dan periodenya lebih dari satu tahun dan dapat berubah dalam waktu yang bersamaan. Dalam ilmu statistik pola pergerakan ini biasa disebut dengan pergerakan siklis atau cyclical movement atau variation.

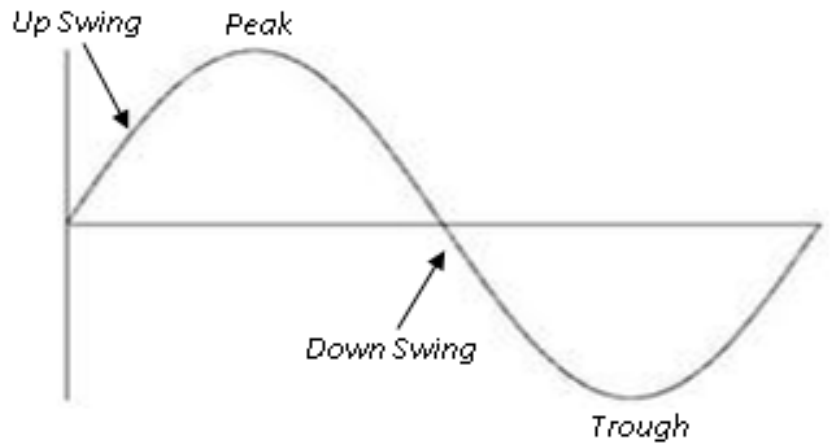

Gambar 3 Siklus Bisnis 
Pergerakan harga kontrak komoditas yang mendasari pergerakan harga kontrak berjangka berperilaku siklus (Colby, 2003; Schofield, 2007), sehingga salah satu cara untuk melakukan analisis fundamental, di mana terdapat siklus pergerakan harga, adalah dengan menggunakan cyclic forecasting atau Seasonal Series (Diebold, 2008), dengan persamaan:

$$
y_{t}=\beta_{1} \operatorname{TIME}+\sum_{i=1}^{s} \gamma_{i} D_{i t}+\varepsilon_{t}
$$

$$
\begin{aligned}
& y_{t}=\text { Predictor } \\
& \beta_{1}=\text { Slope } \\
& \chi=\text { Seasonal Factor (seasonal index) } \\
& D_{i t}=\text { Seasonal dummy variables } \\
& \varepsilon_{t}=\text { Error } \\
& s=12 \text { karena menggunakan data bulanan }
\end{aligned}
$$

Tingkat akurasi dari metode peramalan yang sering digunakan dalam penelitian adalah Mean Squared Error atau MSE (Katz \& Murphy, 2005), dimana semakin kecil MSE berarti semakin kecil rata-rata selisih kuadrat antara nilai aktual dan prediktor, dengan kata lain model peramalannya semakin akurat. MSE dapat ditentukan dengan persamaan (Aczel \& Sounderpandian, 2002):

$$
M S E=\frac{\sum_{t=1}^{T}\left(y_{t}-\hat{y}_{t}\right)^{2}}{T}
$$

$$
\begin{aligned}
y_{t} & =\text { nilai aktual } \\
\hat{y}_{t} & =\text { nilai prediksi (predictor) } \\
T & =\text { jumlah data }
\end{aligned}
$$

Fungsi Solver dalam Ms Excel digunakan untuk menjembatani penentuan persamaan cyclic forecasting dan MSE, karena Solver dapat menjalankan perintah Linear Programming (Barlow, 2005). Objective function adalah minimalisasi MSE dengan variabel seasonal index yang menentukan prediktor cyclical forecasting. Value at Risk (VaR) diperkenalkan oleh JP. Morgan, adalah nilai kerugian maksimum dengan tingkat keyakinan tertentu selama n hari mendatang (Holton, 2003; Hull, 2005), dengan persamaan:

$$
\operatorname{VaR}=V \cdot \sigma \cdot Z_{P} \cdot \sqrt{n}
$$

$$
\begin{aligned}
& V=\text { nilai aset } \\
& \sigma=\text { fluktuasi aset harian } \\
& Z_{P}=\text { Nilai } Z \text { dengan tingkat keyakinan tertentu } \\
& t=\text { jumlah hari mendatang }
\end{aligned}
$$

Penerapan lebih luas dari VaR tidak hanya bermakna kerugian (loss) tetapi juga bermakna positif (gain), sehingga VaR dapat dimanfaatkan untuk mendukung strategi perdagangan di bursa, yaitu sebagai Stop-Loss (Holton, 2003) untuk mengurangi kerugian lebih besar saat pelaku pasar melakukan holding position, serta sebaliknya, $\mathrm{VaR}$ pun dapat dimanfaatkan sebagai Profit-Taking (Frenkel, Hommel \& Rudolf, 2005) untuk mendapatkan laba perdagangan di bursa, sebelum pergerakan harga bursa turun lebih rendah. 


\section{HASIL DAN PEMBAHASAN}

\section{Analisis Pergerakan Harga Kontrak Berjangka CPO 2006 - 2008}

Selama periode 2006, harga rata-rata kontrak berjangka CPO adalah RM 1.568 dengan fluktuasi RM 145,68 per bulan, sedangkan periode 2007, harga rata-ratanya naik signifikan sebesar 1,5 kali dari sebelumnya, menjadi RM 2.398 dengan fluktuasi RM 364,78 per bulan. Kenaikan ini dipicu oleh semakin maraknya penggunaan bahan bakar alternatif (biodiesel) dari CPO yang digunakan oleh industri-industri baik skala regional maupun internasional dan juga peningkatan ekspor terutama ke negara China dan India.

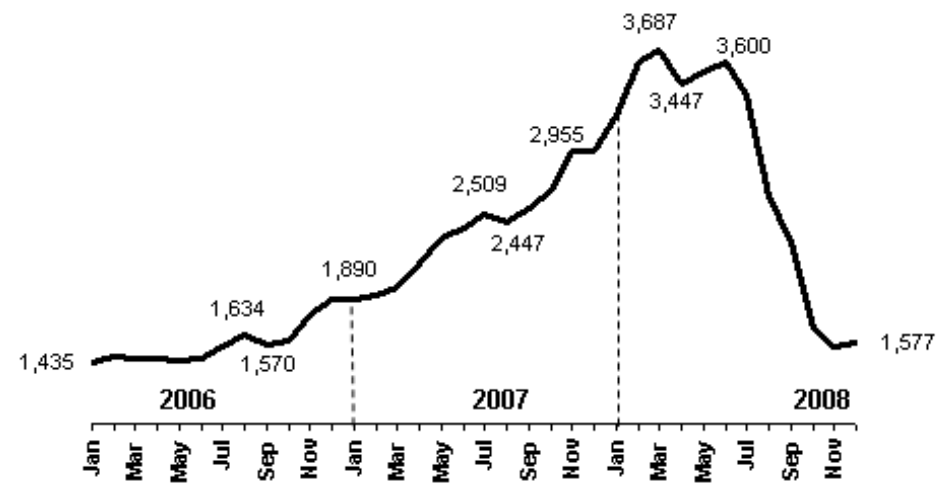

Gambar 4 Pergerakan Rata-Rata Harga Kontrak Berjangka CPO Periode 2006 - 2008 (RM, KLSE)

Pada tahun 2008, harga rata-rata kontrak berjangka CPO kembali naik menjadi RM 2.849, dengan fluktuasi yang lebih besar sebesar RM 853,93 per bulan. Tingkat fluktuasi yang begitu besar dan jatuhnya harga kontrak berjangka CPO dari level 3.500 hingga ke level 1.500 pada semester ke-2 tahun 2008, terjadi akibat pengaruh krisis global yang menyebabkan menurunnya pasar ekspor CPO dan diikuti dengan penurunan harga kontrak berjangkanya. Gambar di atas menunjukkan gejala siklus pergerakan harga, yang dimulai dari titik terendahnya di tahun 2006, kemudian mulai bergerak ke atas (up swing) di tahun 2007, dan mencapai puncaknya (peak) pada semester pertama di tahun 2008. Siklus tersebut berakhir saat terjadi penurunan harga kontrak berjangka CPO (down swing) pada semester kedua di tahun 2008. Data historis selama periode 2006-2008 digunakan sebagai dasar cyclic forecasting untuk tahun 2009-2010.

\section{Cyclic Forecasting Harga Kontrak Berjangka CPO 2009-2010}

Sebagaimana landasan teori yang telah disampaikan sebelumnya, penentuan model peramalan dengan cyclic forecasting akan menggunakan pendekatan Linear Programming (LP) dengan bantuan fungsi Solver pada Ms Excel, yaitu:

Objective Function

Minimize MSE $=\frac{\sum_{t=1}^{T}\left(y_{t}-\hat{y}_{t}\right)^{2}}{T}$ 
Di mana:

$T=24$ (jumlah data, siklus 2 tahunan)

$\hat{y}_{t}=\beta_{1} T I M E+\sum_{i=1}^{s} \gamma_{i} D_{i t}+\varepsilon_{t}$

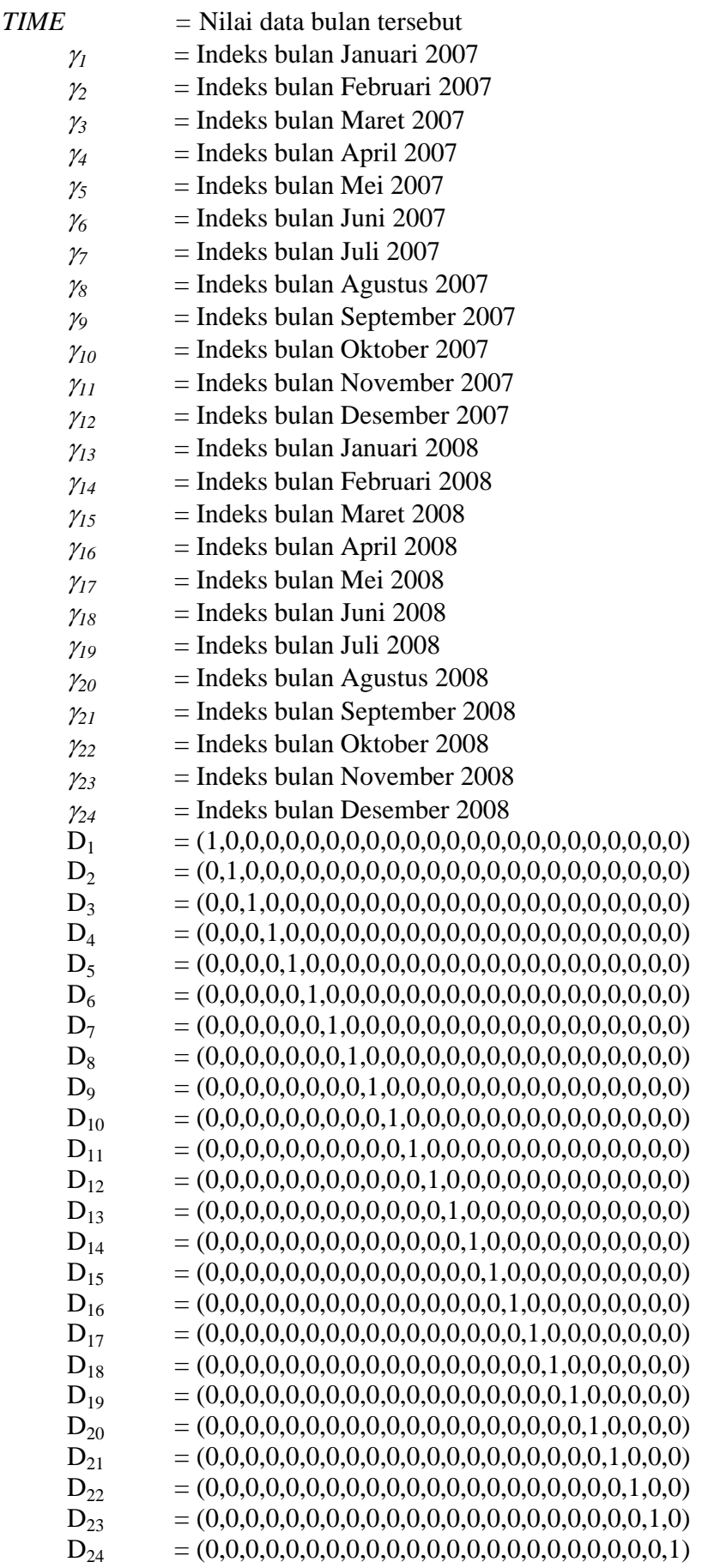

Penerapan dalam Linear Programming dengan fungsi Solver pada Ms Excel adalah: (1) Target Cell: MSE; (2) Equal to: Minimize; (3) Changging Cells : $\beta$ (beta), $\mathrm{D}_{1}-\mathrm{D}_{24}, \gamma_{1}-\gamma_{24}$, Error (intercept); (4) Constraints: tidak ada; (5) Max Time: 100 seconds; (6) Iterations:100;(7)Precessions: 
0,0000001; (8) Tolerance: 5\%; (9) Convergence: 0,0001; (10) Estimates: Tangent; (11) Derivatives: Forward; (12) Search: Newton.

Pembukaan kontrak berjangka CPO awal tahun 2007 dimulai dari bulan Desember 2006, sehingga index bulan Desember (tahun sebelumnya) digunakan sebagai seasonal index pertama dan berakhir sampai dengan November (tahun sesudahnya). Mengingat fluktuasi dan pertumbuhan selama periode 2006 relatif rendah daripada periode 2007 dan 2008, maka data historis yang digunakan untuk meramalkan harga kontrak berjangka periode 2009 adalah data periode Januari 2007-Januari 2008, hal ini juga relevan dengan gejala siklus seperti yang terjadi pada Gambar 4 (tanpa periode 2006). Data harga kontrak berjangka CPO dalam RM (Ringgit Malaysia). Tampilan awal lembar kerja (worksheet) seperti pada Tabel 1.

Tabel 1 Worksheet Awal Penentuan Seasonal Index dengan Linear Programming

\begin{tabular}{|c|c|c|c|c|c|}
\hline Wonth & TINE & $\begin{array}{l}\text { Avg. Futures } \\
\text { Price (RM) }\end{array}$ & $\begin{array}{c}\text { Seasomai } \\
\text { index }\end{array}$ & Predictor & $\begin{array}{l}\text { Soldared } \\
\text { Error }\end{array}$ \\
\hline Jaח 07 & 39,063 & 1,690 & 0.0000 & 0 & $3,573,720.18$ \\
\hline Feb 07 & 39,114 & 1,927 & 0.0000 & 0 & $3,711,742.23$ \\
\hline Mar 07 & 39,142 & 1,975 & 0.0000 & 0 & $3,900,445.46$ \\
\hline Apr 07 & 39,173 & 2,145 & 0.0000 & 0 & $4,600,610,50$ \\
\hline Way of & 39,203 & 2,341 & 0.0000 & 0 & $5,478,943.37$ \\
\hline Juח 07 & 39,234 & 2,410 & 0.0000 & 0 & $5,807,870.48$ \\
\hline الs 07 & 39,264 & 2,509 & 0.0000 & 0 & $6 ; 296 ; 221.51$ \\
\hline A.tg 07 & 39,295 & 2,447 & 0.0000 & 0 & $5,966,253,92$ \\
\hline Sep of & 39,326 & 2,545 & 0.0000 & 0 & $6,478,606.62$ \\
\hline Oct 07 & 39,356 & 2,680 & 0.0000 & 0 & $7,180,694.65$ \\
\hline Nov 07 & 39,387 & 2,955 & 0.0000 & 0 & $8,732,587.87$ \\
\hline Dec 07 & 39,417 & 2,956 & 0.00000 & 0 & $8,736,558,33$ \\
\hline Jan 08 & 39,448 & 3,219 & 0.0000 & 0 & $10,360,029.69$ \\
\hline Feb 08 & 39,479 & 3,599 & 0.0000 & 0 & $12,953,600.79$ \\
\hline Mar 08 & 39,508 & 3,687 & 0.0000 & 0 & $13,595,812.56$ \\
\hline Apr 08 & 39,539 & 3,447 & 0.0000 & 0 & $11,879,302.22$ \\
\hline May 08 & 39,569 & 3,529 & 0.0000 & 0 & $12,451,017.96$ \\
\hline ग 08 & 39,600 & 3,586 & 0.00000 & 0 & $12,873,402.29$ \\
\hline 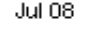 & 39,630 & 3,356 & 0.0000 & 0 & $11,265,362.59$ \\
\hline Aug 08 & 39,661 & 2,636 & 0.0000 & 0 & $6,960,802.78$ \\
\hline Sep 08 & 39,692 & 2,311 & 0.0000 & 0 & $5,341,381,31$ \\
\hline Oct 08 & 39,722 & 1,683 & 0.0000 & 0 & $2,832,152.41$ \\
\hline Nov 08 & 39,753 & 1,551 & 0.0000 & 0 & $2,404,670.49$ \\
\hline Dec 06 & 39,763 & 1,577 & 0.0000 & 0 & $2,485,509.90$ \\
\hline & Beta = & 0.0000 & & $\mathrm{SSE}=$ & $175,891,700.09$ \\
\hline Error & cept) = & 0.0000 & & MSE = & $7,328,620.84$ \\
\hline
\end{tabular}

Tabel 2 Worksheet Solusi Penentuan Seasonal Index dengan Linear Programming

\begin{tabular}{|c|c|c|c|c|c|}
\hline Month & TMNE & $\begin{array}{l}\text { Avg. Futures } \\
\text { Arice (RM) }\end{array}$ & $\begin{array}{l}\text { Seasonal } \\
\text { index }\end{array}$ & Predictor & $\begin{array}{l}\text { Souared } \\
\text { Error }\end{array}$ \\
\hline Jan 07 & 39,083 & 1,690 & -696.7613 & 1,904 & 160.06 \\
\hline Feb 07 & 39,114 & 1,927 & -663.3044 & 1,939 & 163.52 \\
\hline wat of & 39,142 & 1,975 & -617.6926 & 1,967 & 141.70 \\
\hline Apr or & 39,173 & 2,145 & -452.9572 & 2,154 & 75.96 \\
\hline May of & 39,203 & 2,341 & -262.8910 & 2,346 & 25.22 \\
\hline . & 39,234 & 2410 & -196.9982 & 2,414 & 14.05 \\
\hline 罗 & 39,264 & 2,509 & -101.5677 & 2,511 & 3.64 \\
\hline Aug 07 & 39,295 & 2,447 & -164.5485 & 2,450 & 9.83 \\
\hline Sep 07 & 39,326 & 2,545 & -70.1869 & 2,547 & 1.72 \\
\hline oot or & 39,356 & 2,680 & 59.6254 & 2,678 & 1.45 \\
\hline Nov 07 & 39,387 & 2,955 & 327.7599 & 2,949 & 41.12 \\
\hline Dec 07 & 39,417 & 2,956 & 326.6007 & 2,950 & 40.67 \\
\hline Jan 08 & 39,446 & 3,219 & 562.3623 & 3,207 & 126.57 \\
\hline Feb 08 & 39,479 & 3,599 & 953.4963 & 3,581 & 343.81 \\
\hline Mar 08 & 39,508 & 3,687 & $1,038.0552$ & 3,667 & 407.49 \\
\hline Apr 08 & 39,539 & 3,447 & 800.0065 & 3,431 & 241.80 \\
\hline May 08 & 39,569 & 3,529 & 878.4448 & 3,512 & 291.40 \\
\hline . & 39,600 & 3,588 & 934.6493 & 3,570 & 329.31 \\
\hline 少 08 & 39,630 & 3,356 & 705.5490 & 3,343 & 187.18 \\
\hline Aug 08 & 39,661 & $2,6: 38$ & -0.8477 & 2,638 & 0.00 \\
\hline sep 08 & 39,692 & 2,311 & -323.8163 & 2,317 & 40.26 \\
\hline ot 08 & 39,722 & 1,683 & -942.0365 & 1,701 & 337.46 \\
\hline Nov 00 & 39,753 & 1,551 & $-1,073.7410$ & 1,572 & $4: 30.41$ \\
\hline Dec 08 & 39,763 & 1,577 & $-1,050,3432$ & 1,597 & 419.90 \\
\hline & $\mathrm{a}=$ & 0.0668 & & SSE & $3,664.55$ \\
\hline & ercept = & -11.0396 & & MSE = & 161.02 \\
\hline
\end{tabular}


Agar lebih mudah melakukan analisis, hasil dari Tabel 2 disusun dalam bentuk grafik, termasuk hasil peramalan untuk periode 2009, adalah seperti pada Gambar 5.

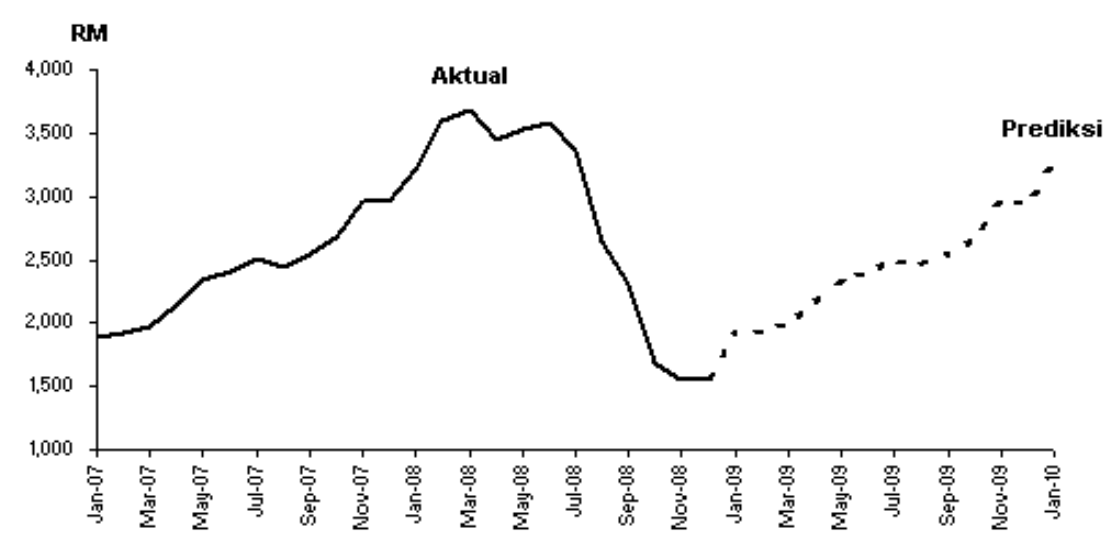

Gambar 5 Peramalan rata-rata harga kontrak berjangka CPO Periode 2009

Tabel 2 dapat meningkatkan akurasi model cyclic forecasting, ditandai dengan penurunan drastis MSE yang sebelumnya sebesar 7.328.820,84 menjadi 161,02, persamaan model peramalan adalah :

$$
\hat{y}_{t}=0,0668 . T I M E+\sum_{i=1}^{s} \gamma_{i} D_{i t}-11,0396
$$

Beta sebesar 0,0668 menunjukkan bahwa sensitivitas TIME terhadap prediksi rata-rata harga kontrak berjangka CPO di KLSE adalah relatif rendah dan berbanding lurus, dengan kata lain, seasonal index selama 24 bulan data historis yang terlibat dalam model $\left(\gamma_{1}-\gamma_{24}\right)$ yang memang signifikan terhadap perubahan variabel terikat. Error (intercept) negatif menunjukkan bahwa hasil prediksi sering terlalu tinggi sehingga perlu disesuaikan dengan pengurangan \pm RM 11 dari sebelumnya. Analisis hasil peramalan (garis putus-putus) akan diurai bertahap, disesuaikan dengan periode analisis simulasi back-testing yang dilengkapi dengan Stop-Loss dan Profit Taking berdasarkan Value at Risk (VaR). Catatan: Penggunaan model cyclic forecasting di atas harus menggunakan komputer yang memiliki RAM minimal 1 Gigabyte, karena mengacu pada pendapat Diebold (2008) yaitu your computer will scream at you if you run such regression.

\section{Trading Policy dan Trading Strategy}

Sebelum memulai simulasi, terdapat beberapa hal yang perlu dibahas, terutama tentang kondisi awal investor dan strategi perdagangan. Pertama, data historis kontrak berjangka CPO berkode FCPO di KLSE dengan masa jatuh tempo 3 bulan. Saldo awal (opening balance) simulasi ditentukan sebesar RM 20.000 berdasarkan peraturan KLSE. Kedua, simulasi back-testing tidak akan menggunakan short-selling. Ketiga, VaR digunakan sebagai batasan Stop Loss untuk mengurangi risiko yang lebih besar selama periode simulasi. VaR ditentukan berdasarkan confidence level $90 \%$ untuk 2 bulan mendatang (jumlah hari disesuaikan) dengan fluktuasi (standard deviation) dari tingkat laba harian kontak berjangka CPO.

Kemudian, guna mengurangi tindakan spekulatif, bila VaR lebih dari 200 poin, maka VaR akan disesuaikan menjadi 200 poin, sehingga Stop Loss = harga beli - VaR dan Take Profit = Harga beli + VaR. Tingkat laba bulanan kontrak berjangka CPO ditentukan dengan metode aritmatika untuk memudahkan perhitungan. Entry market akan dilakukan bila harga kontrak berjangka saat itu lebih rendah atau relatif sama dengan prediksinya. Selain itu, exit market akan dilakukan bila: harga kontrak 
berjangka saat itu sama dengan Take Profit (uptrend), untuk mendapatkan target harga berdasarkan hasil cyclic forecasting, walaupun belum mencapai jatuh tempo 2 bulan dan harga kontrak berjangka saat itu sama dengan Stop Loss (downtrend), untuk mengurangi kerugian yang lebih besar, walaupun belum mencapai jatuh tempo 2 bulan.

Setiap posisi jual dibatasi sebesar 1 kontrak saja, mengingat simulasi ini ditujukan untuk investor pemula, guna mengurangi transaksi yang terlalu spekulatif agar konsisten dengan konsep normal risk. Initial margin transaksi intraday (perdagangan harian) adalah RM 5.500 untuk 1 kontrak, sedangkan untuk position trade (perdagangan bulanan) diperlukan RM 10.000 untuk 1 kontrak. Di lain pihak, simulasi harus turut "mematuhi" peraturan bursa untuk menjaga maintenance margin sebesar RM 7.500. Alasan-alasan tersebut yang membuat simulasi ini hanya bisa menggunakan 1 kontrak setiap terjadi transaksi jual.

Biaya komisi setiap transaksi adalah RM 100, biaya tersebut dibebankan saat melakukan posisi jual (exit market). Setiap perubahan 1 poin harga kontrak berjangka di bursa bernilai RM 25 (peraturan bursa KLSE), maka setiap perubahan tersebut akan diperhitungkan untuk menentukan Gain atau Loss setiap transaksi yang terjadi. Pajak transaksi perdagangan belum diperhitungkan. Pergerakan harga kontrak berjangka CPO diasumsikan bergerak secara kontinyu maka harga kontrak berjangka CPO akan dipantau setiap hari sampai dengan close position. Ukuran kinerja simulasi back-testing perdagangan ditentukan berdasarkan Return On Margin (ROM).

\section{Simulasi Back-Testing Perdagangan Kontrak Berjangka CPO Periode Januari-Maret 2009}

Berdasarkan data historis dan hasil model cyclic forecasting, dapat ditentukan bahwa rata-rata harga kontrak berjangka Desember 2008 adalah RM 1.577 yang diramalkan dalam 2 bulan mendatang akan naik menjadi rata-rata sebesar RM 1.939 (Februari 2009), seperti pada Gambar 6.

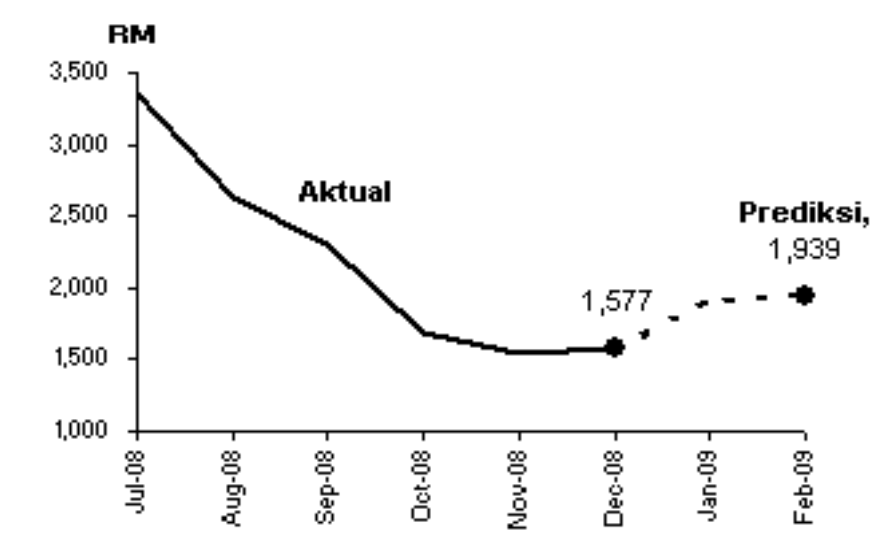

Gambar 6 Peramalan Rata-Rata Harga Kontrak Berjangka CPO Periode Januari-Februari 2009

Fluktuasi tingkat laba kontrak berjangka CPO (selanjutnya disebut dengan FCPO, singkatan dari Futures CPO) selama 6 bulan terakhir (1 Juli 2008-31 Desember 2008) berdasarkan grafik di atas adalah 3,69\% per hari. Harga FCPO pada 2 Januari 2009 adalah RM 1.739, simulasi akan melakukan Entry market pada tanggal tersebut karena diramalkan akan naik menjadi (rata-rata) RM 1.939 pada akhir Februari 2009, dengan trading strategy sebagai berikut: 
$\begin{aligned} \mathrm{VaR} & =1.739 \times 3,69 \% \times 1,64 \times \sqrt{37} \\ & =642 \text { poin }\end{aligned}$

Penyesuaian VaR dari 642 menjadi 200 poin, berdasarkan trading policy ke-3 di halaman sebelumnya, maka:

$\begin{array}{ll}\text { Open Buy (Buying price) } & =\text { RM } 1.739 \\ \text { Stop Loss }=1.739-200 & =\text { RM } 1.539 \\ \text { Take Profit }=1.739+200 & =\text { RM } 1.939\end{array}$

Transaksi ini menunggu sampai dengan target take profit pada tingkat harga RM 1.939. Berdasarkan data simulasi, transaksi harus ditutup (close sell) pada tanggal 10 Februari 2009 karena pada hari tersebut harga penutupan sudah menembus target, yaitu RM 1.962, maka perhitungan gain atau loss adalah:

\begin{tabular}{ll} 
Gross $P / L=(1.962-1.739)$ poin $\times$ RM 25 per poin & $=R M 5.575$ \\
Less Fee & $=R M \quad-100$ \\
\hline Net $P / L$ & $=R M 5.475$
\end{tabular}

Initial Margin $=R M 20.000$

Net $P / L=R M \quad 5.475$

Cash Balance $=R M 25.475 \quad$ (10 Februari 2009)

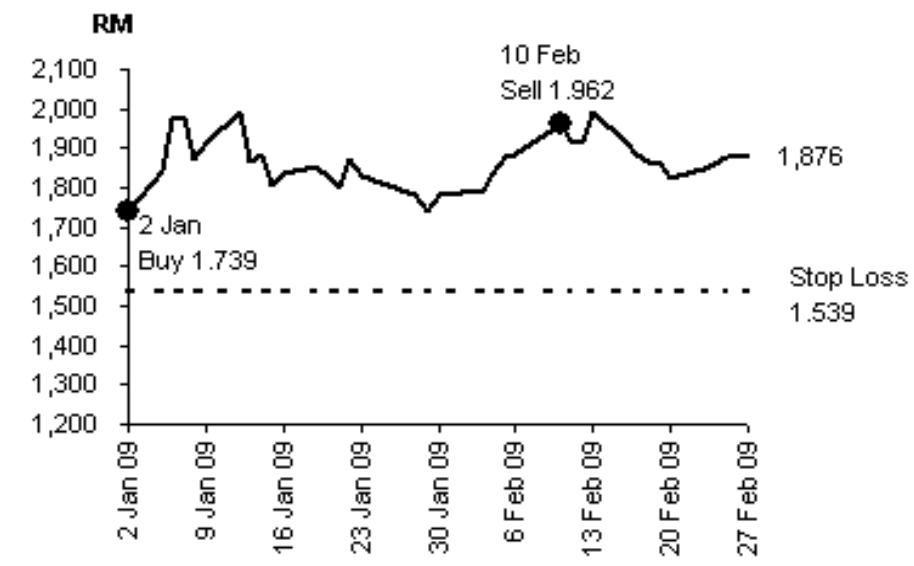

Gambar 7 Perkembangan harga aktual harian kontrak berjangka CPO periode Januari-Feb 2009

Simulasi dilanjutkan pada periode berikutnya, Maret-April 2009, pada bulan Maret 2009 diramalkan rata-rata harga FCPO akan mencapai RM 2.154, yang fluktuasi tingkat laba harian FCPO selama 6 bulan terakhir (2 September 2008-27 Februari 2009) mencapai 3,67\% per hari. 


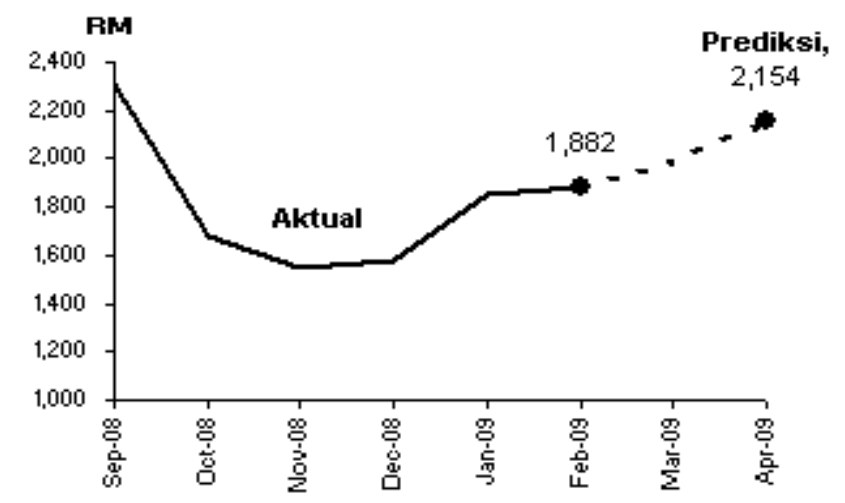

Gambar 8 Peramalan Rata-Rata Harga Kontrak Berjangka CPO Periode Maret-April 2009

Trading strategy yang akan dilakukan pada 2 Maret 2009 (FCPO = RM 1.851) adalah:

$\begin{aligned} \mathrm{VaR} & =1.851 \times 3,67 \% \times 1,64 \times \sqrt{ } 43 \\ & =733 \text { poin }\end{aligned}$

(2 Mar 2008 - 30 Apr 2009)

(pembulatan)

Penyesuaian VaR dari 733 menjadi 200 poin, berdasarkan trading policy ke-3 di halaman sebelumnya, maka:

Open Buy (Buying price) = RM 1.851

Stop Loss $=1.851-200=\mathrm{RM} 1.651$

Take Profit $=1.851+200=$ RM 2.051

Transaksi ini menunggu sampai dengan target Take Profit pada tingkat harga RM 2.051. Berdasarkan data simulasi, transaksi harus ditutup (Close Sell) pada tanggal 2 April 2009 karena pada hari tersebut harga penutupan sudah menembus target, yaitu RM 2.120, maka perhitungan Gain atau Loss adalah:

\begin{tabular}{lr} 
Gross $P / L=(2.120-1.851)$ poin $\times$ RM 25 per poin & $=R M 6.725$ \\
Less Fee & $=R M \quad-100$ \\
\hline Net $P / L$ & $=R M 5.725$
\end{tabular}

$\begin{array}{lll}\text { Beginning Cash Balance } & =R M 25.475 & (10 \text { Februari 2009) } \\ \text { Net P/L } & \text { RM } & 5.725 \\ \text { Ending Cash Balance } & =R M 32.100 & (2 \text { April 2009) }\end{array}$

Dalam kenyataannya, harga FCPO setelah 2 April 2009 tetap naik tertinggi sampai dengan RM 2.610 (22 April 2009), kemudian terkoreksi kembali sampai ke RM 2.535 (30 April 2009). Simulasi back-testing tetap konsisten menjalankan trading policy, yang membuat harus exit market pada tanggal 2 April 2009. 


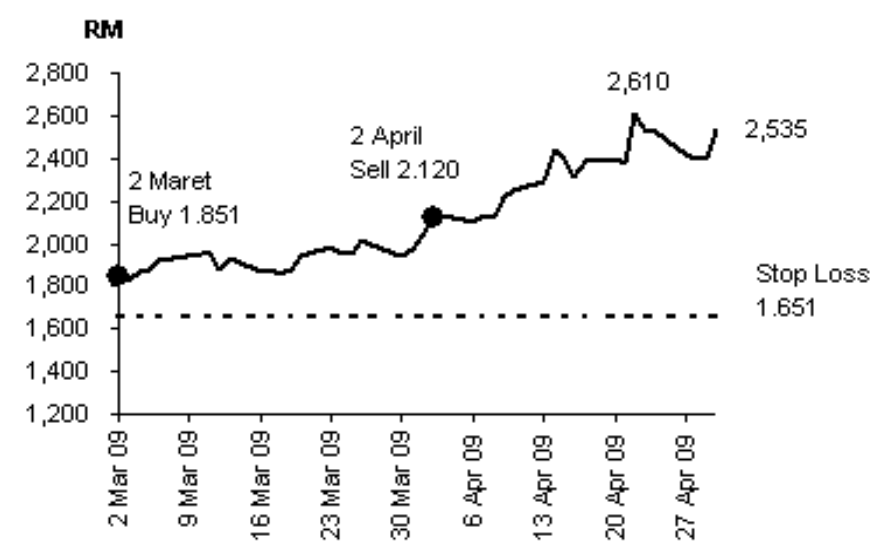

Gambar 9 Perkembangan harga aktual harian kontrak berjangka CPO periode Maret-April 2009

Sampai dengan transaksi ke-2, pergerakan harga FCPO belum pernah melewati Stop Loss ke-2 transaksi tersebut dan selalu berakhir sebelum jatuh tempo. Simulasi dilanjutkan ke periode berikutnya, Mei-Juni 2009, dimana fluktuasi tingkat laba harian FCPO selama 6 bulan terakhir (1 Desember 2008-30 April 2009) adalah 2,95\% per hari, jauh lebih rendah daripada 2 periode sebelumnya. Rata-rata harga aktual FCPO pada bulan April 2009 adalah RM 2.569 sedangkan harga FCPO saat 4 Mei 2009 adalah RM 2.641. Berdasarkan model peramalan, harga rata-rata FCPO diramalkan akan turun ke RM 2.414 pada bulan Juni 2009, dengan ilustrasi pada Gambar 10.

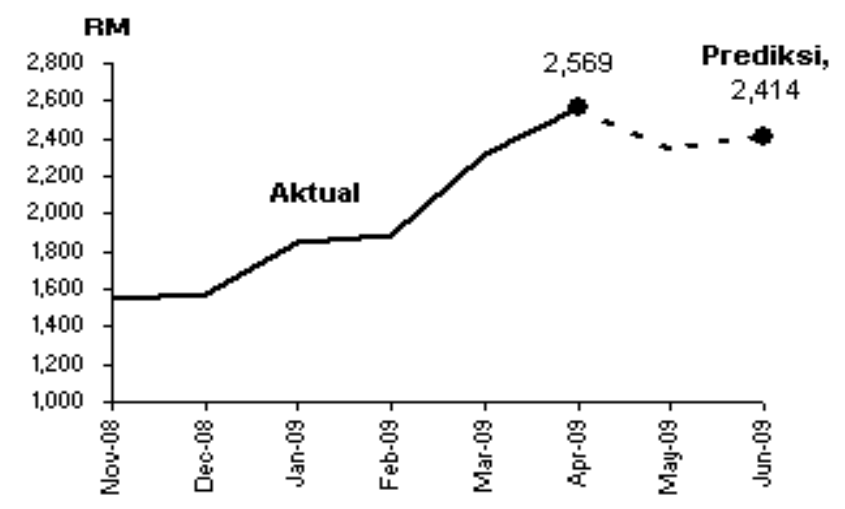

Gambar 10 Peramalan rata-rata harga kontrak berjangka CPO periode Mei-Juni 2009

Grafik di atas menunjukkan bahwa peramalan pergerakan rata-rata harga FCPO dari AprilJuni 2009 akan mengalami penurunan. Posisi trader yang bisa dimanfaatkan untuk mendapatkan keuntungan saat downtrend tersebut adalah Short-Selling, tetapi simulasi terpaksa hanya melakukan wait \& see sampai akhir bulan Juni 2009, sebab posisi short-selling tidak konsisten dengan trading policy ke-3. Meskipun demikian, penelitian ini akan menganalisis pergerakan aktual selama periode Mei-Juni 2009, seperti pada Gambar 11. 


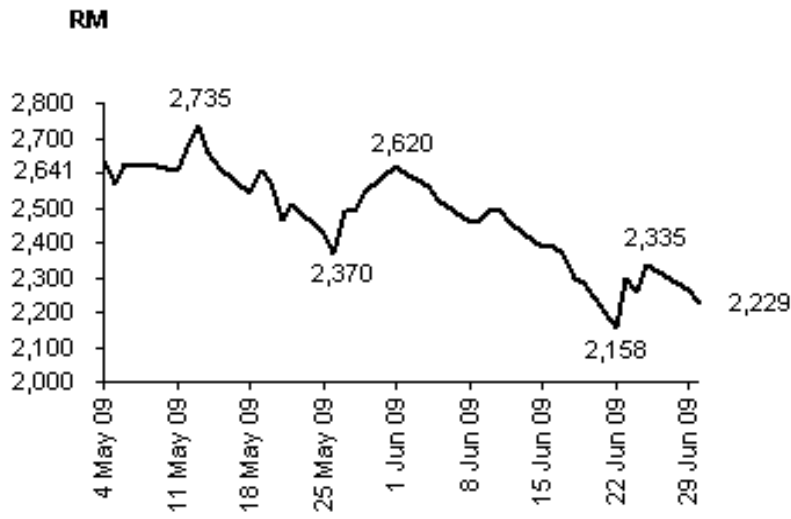

Gambar 11 Perkembangan Harga Aktual Harian Kontrak Berjangka CPO Periode Mei-Juni 2009

Pergerakan harga FCPO di pertengahan Mei 2009 sempat mencapai titik tertinggi yaitu RM 2.735 atau naik 94 poin dibandingkan dengan awal Mei 2009 yang hanya mencapai RM 2.641. Meskipun demikian pergerakan harganya memang mengalami downtrend dengan beberapa kali terkoreksi, yang akhirnya pada 30 Juni 2009 menjadi RM 2.229, atau turun 412 poin dibandingkan pada awal Mei 2009. Trading strategy simulasi dinilai tepat karena melakukan wait \& see selama periode Mei-Juni 2009, berdasarkan model cyclical forecasting.

Analisis simulasi dilanjutkan kembali untuk periode berikutnya, Juli-Agustus 2009, diramalkan dari Juni 2009 yang rata-rata harga FCPO sebesar RM 2.400 akan naik sedikit menjadi RM 2.450 pada bulan Agustus 2009, dengan fluktuasi 6 bulan terakhir (3 Februari-30 Juni 2009) adalah RM 2,68\% per hari.

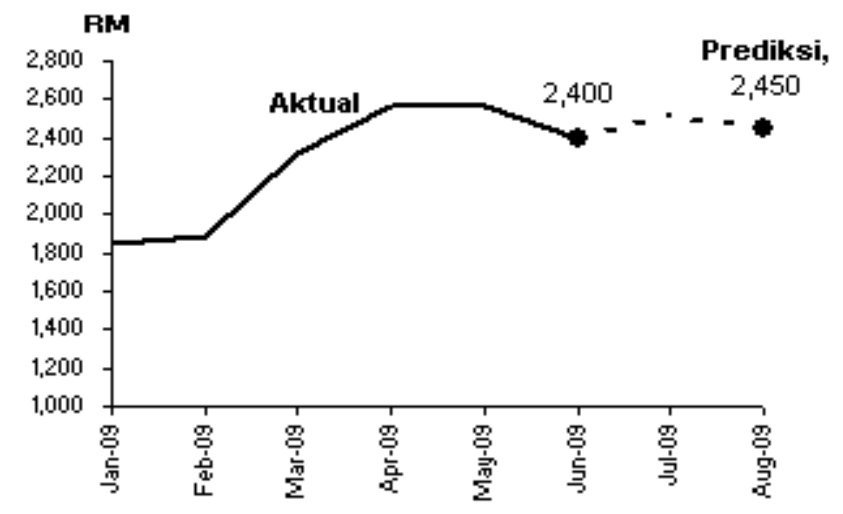

Gambar 12 Peramalan Rata-Rata Harga Kontrak Berjangka CPO Periode Juli-Agustus 2009

Harga FCPO pada tanggal 1 Juli 2009 adalah RM 2.258, lebih rendah dari rata-rata harga FCPO pada bulan Juni 2009, berdasarkan hal tersebut, maka trading strategy yang akan dilakukan adalah:

$$
\begin{aligned}
\mathrm{VaR} & =2.258 \times 2,68 \% \times 1,64 \times \sqrt{ } 43 \\
& =652 \text { poin }
\end{aligned}
$$


Penyesuaian VaR dari 652 menjadi 200 poin, berdasarkan trading policy ke-3 di halaman sebelumnya, maka:

Open Buy (Buying price) = RM 2.258

Stop Loss $=2.258-200=\mathrm{RM} 2.058$

Take Profit $=2.258+200=$ RM 2.458

Transaksi ini menunggu sampai dengan target Take Profit pada tingkat harga RM 2.458. Berdasarkan data simulasi, pada tanggal 8 Juli 2009 pergerakan harga FCPO sudah menembus batas Stop Loss (RM 2.058) yaitu pada tingkat harga RM 2.001. Hal ini membuat simulasi harus melakukan exit market pada tanggal tersebut-konsisten dengan trading strategy ke-7, maka perhitungan Gain atau Loss adalah:

\begin{tabular}{|c|c|c|}
\hline $\begin{array}{l}\text { Gross P/L } \\
\text { Less Fee }\end{array}$ & $=(2.001-2.258)$ poin $x$ RM 25 per poin & $\begin{array}{l}=R M-6.425 \\
=R M \quad-100\end{array}$ \\
\hline Net P/L & & 6.525 \\
\hline
\end{tabular}

\begin{tabular}{lrl} 
Beginning Cash Balance & $=R M 32.100$ & (1 Juli 2009) \\
Net P/L $=R M-6.525$ & \\
\hline Ending Cash Balance & $=R M 25.575$ & (8 Juli 2009)
\end{tabular}

Dalam prakteknya, kondisi seperti ini sebenarnya masih dapat dimanfaatkan kembali dengan entry market untuk yang kedua kali pada periode yang sama, terutama pada saat pergerakan harga FCPO sudah relatif jauh dengan stop loss, yaitu ditunggu sampai menembus batas resisten awal Juli (RM 2.258), tepatnya 3 Agustus yang sebesar RM 2.287. Simulasi kemudian diteruskan dengan harapan harga akan bergerak menuju target RM 2.450 (hasil peramalan bulan Agustus 2009). Akhirnya, harga bergerak menembus target pada 13 Agustus 2009, yang membuat simulasi harus melakukan exit market pada harga RM 2.489. Berikut ilustrasi trading strategy dan pergerakan harga FCPO selama Juli-Agustus 2009 (Gambar 13).

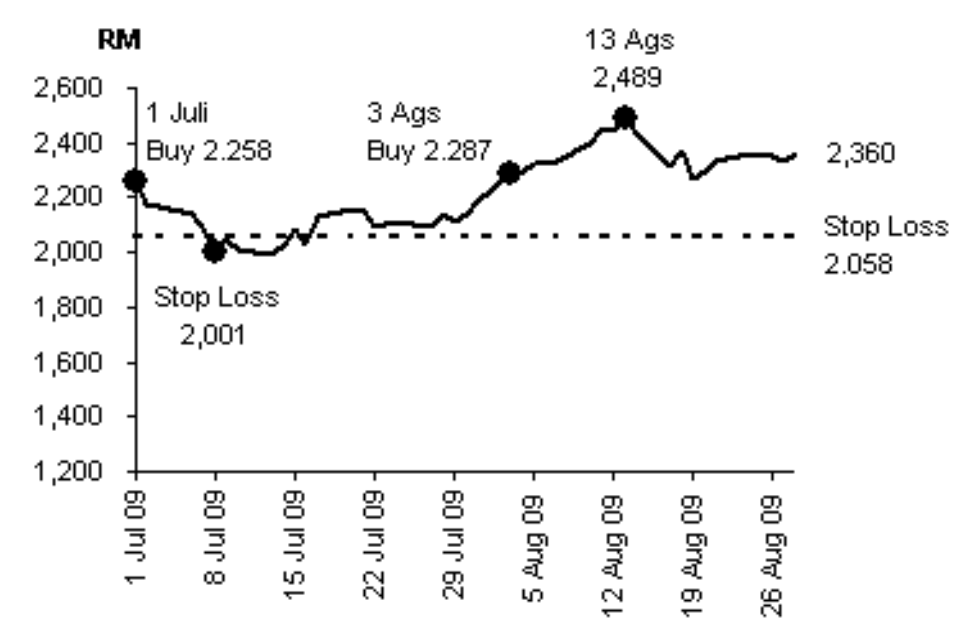

Gambar 13 Perkembangan Harga Aktual Harian Kontrak Berjangka CPO Periode Juli-Agustus 2009 
$\begin{array}{ll}\text { Open Buy (Buying price) } & =\text { RM 2.287 } \\ \text { Stop Loss }=2.287-200 & =\text { RM 2.087 } \\ \text { Take Profit }=2.287+200 & =\text { RM 2.487 }\end{array}$

$\begin{aligned} & \text { Gross } P / L=(2.489-2.287) \text { poin } x \text { RM } 25 \text { per poin } \\ & \text { Less Fee }\end{aligned} \quad$ RM 5.050
Net $P / L$

Beginning Cash Balance $\quad=$ RM $25.575 \quad$ (8 Juli 2009)

Net $P / L=R M \quad 4.950$

Ending Cash Balance $\quad=R M 30.525 \quad$ (13 Agustus 2009)

Simulasi dilanjutkan periode berikutnya, yaitu September-Oktober 2009, dimana rata-rata harga FCPO mulai berbalik arah (reversal) cenderung naik sampai dengan RM 2.678 pada bulan Oktober 2009. Fluktuasi tingkat laba harian FCPO selama 6 bulan terakhir (1 April-28 Agustus 2009) sebesar 2,71\% per hari, mirip dengan fluktuasi periode sebelumnya.

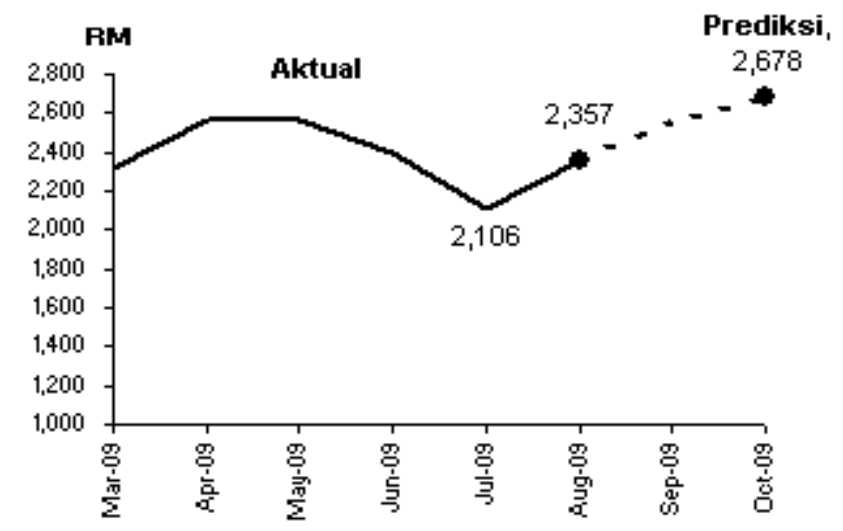

Gambar 14 Peramalan Rata-Rata Harga Kontrak Berjangka CPO Periode September-Oktober 2009 adalah:

Harga FCPO pada tanggal 1 September 2009 adalah RM 2.296, maka trading strategy-nya

(1 September - 30 Oktober 2009) (pembulatan)

Penyesuaian VaR dari 662 menjadi 200 poin, berdasarkan trading policy ke-3 di halaman sebelumnya, maka:

$\begin{array}{ll}\text { Open Buy (Buying price) } & =\text { RM 2.296 } \\ \text { Stop Loss }=2.296-200 & =\text { RM } 2.096 \\ \text { Take Profit }=2.296+200 & =\text { RM } 2.496\end{array}$

Dalam perkembangannya sejak tanggal 1 September 2009, pemantauan pergerakan harga harian FCPO menembus Stop Loss pada 14 September 2009, hal ini membuat simulasi terpaksa melakukan exit market pada harga RM 2.064, dengan perhitungan Gain atau Loss sebagai berikut: 


Gross $P / L=(2.064-2.296)$ poin $x$ RM 25 per poin $\begin{array}{r}=R M-5.800 \\ =R M-100\end{array}$
$\begin{array}{ll}\text { Less Fee } & =R M-5.900\end{array}$

\begin{tabular}{|c|c|c|}
\hline Beginning Cash Balance & $=R M 30.525$ & (13 Agustus 2009) \\
\hline Net P/L & $=R M-5.900$ & \\
\hline ance & $=R M 24.625$ & (14 Septembe \\
\hline
\end{tabular}

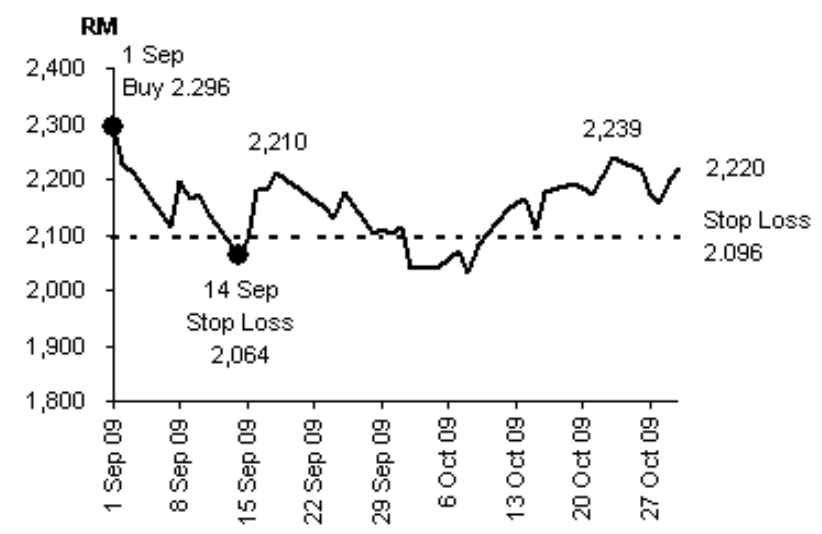

Gambar 15 Perkembangan Harga Aktual Harian Kontrak Berjangka CPO Periode September-Oktober 2009

Periode terakhir simulasi adalah November-Desember 2009, diramalkan bahwa rata-rata harga FCPO akan bergerak naik sampai RM 2.950 pada Desember 2009, dengan fluktuasi 6 bulan terakhir (1 Juni-30 Oktober 2009) sebesar 2,23\% per hari. Harga FCPO pada 2 November 2009 adalah RM 2.221 .

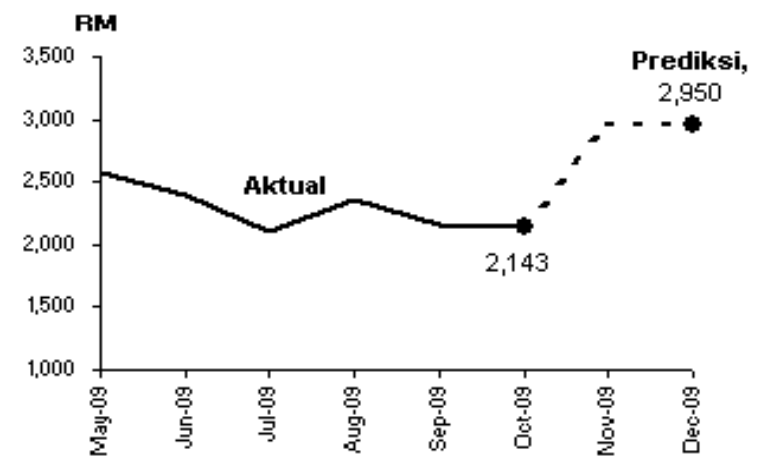

Gambar 16 Peramalan Rata-Rata Harga Kontrak Berjangka CPO Periode November-Desember 2009

Trading strategy yang akan dilakukan adalah:

$$
\begin{aligned}
\mathrm{VaR} & =2.221 \times 2,23 \% \times 1,64 \times \sqrt{ } 41 & & \text { (2 November }-31 \text { Desember 2009) } \\
& =521 \text { poin } & & \text { (pembulatan) }
\end{aligned}
$$


Penyesuaian VaR dari 521 menjadi 200 poin, berdasarkan trading policy ke-3 di halaman sebelumnya, maka:

$\begin{array}{ll}\text { Open Buy (Buying price) } & =\text { RM } 2.221 \\ \text { Stop Loss }=2.221-200 & =\text { RM } 2.021 \\ \text { Take Profit }=2.221+200 & =\text { RM } 2.421\end{array}$

Sejak 2 November 2009, pergerakan harga harian FCPO cenderung naik, sempat beberapa kali hampir menembus target Take Profit, akhirnya target tersebut tercapai saat harga mencapai RM 2.499 pada 23 November 2009, maka perhitungan Gain atau Loss adalah sebagai berikut:

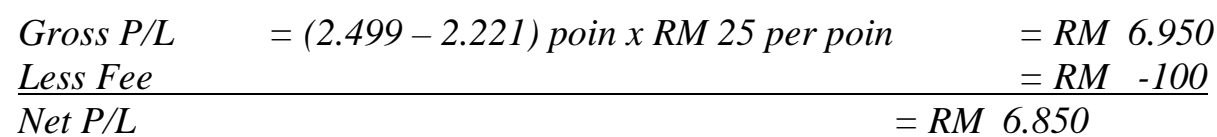

Beginning Cash Balance $\quad=$ RM $24.625 \quad$ (14 September 2009)

Net P/L $=R M \quad 6.850$

Ending Cash Balance $\quad=R M 31.475 \quad$ (23 November 2009)

Gambar 17 mengilustrasi trading strategy yang dilakukan pada bulan November-Desember 2009.

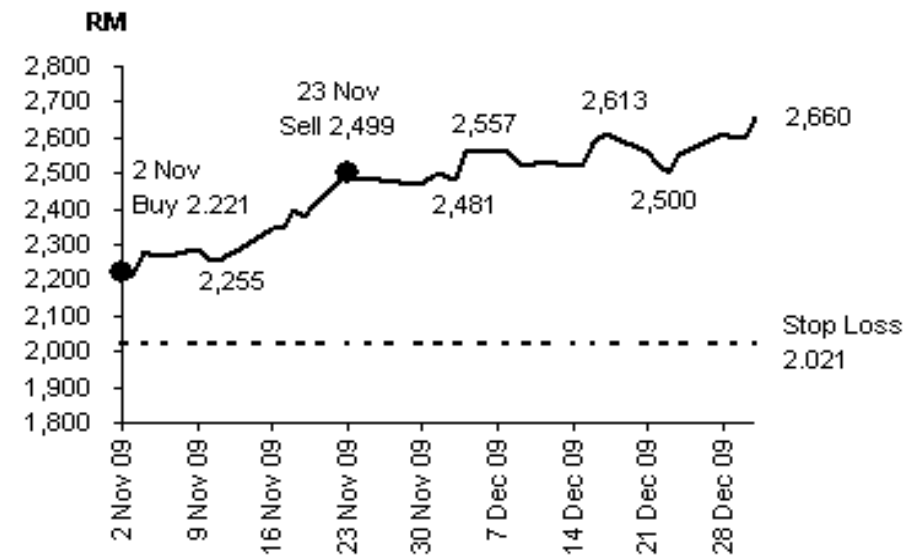

Gambar 17 Perkembangan Harga Aktual Harian Kontrak Berjangka CPO Periode November-Desember 2009

Sejak 23 November 2009 sampai akhir tahun 2009, pergerakan FCPO memang berfluktuatif dengan kecenderungan arah trend naik, bahkan mencapai RM 2.660 pada 31 Desember 2009, yang berarti tingkat harga tersebut relatif dekat dengan harga FCPO saat 2 November ditambah dengan VaR sebelum penyesuaian, yaitu RM $2.221+521=$ RM 2.742. Hasil aktual harga FCPO belum dapat mencapai tingkat harga yang diramalkan oleh model, yaitu rata-rata harga FCPO pada bulan Desember 2009 adalah RM 2.950. 
Tabel 3 Action list selama simulasi Januari-Desember 2009

\begin{tabular}{|c|c|c|c|c|c|c|c|}
\hline Mo & Action & Buy & Sell & Gross $P / L$ & Fee & Balance & ROH \\
\hline 1 & 2 Jan Opening Balance & - & - & - & - & 20,000 & \\
\hline 2 & $2 \operatorname{san}$ Open & 1,739 & - & - & - & 20,000 & \\
\hline 3 & 10 Feb Close & - & 1,962 & 5,575 & 100 & 26,475 & $27.9 \%$ \\
\hline 4 & 2 Mar Open & 1,851 & - & 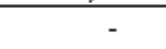 & 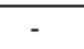 & 25,475 & \\
\hline 5 & 2 Apr Close & - & 2,120 & 6.725 & 100 & 32,100 & $33.6 \%$ \\
\hline 6 & 4 Mal Wait \& See & - & - & - & - & 32,100 & \\
\hline 7 & 7 Ju Open & 2,268 & - & - & - & 32,100 & \\
\hline 8 & 8 jul Close (Stop Loss) & - & 2,001 & $(6.425)$ & 100 & 25,575 & $-32.1 \%$ \\
\hline 9 & 3Aug Open & 2,287 & - & . & - & 25,575 & \\
\hline 10 & 13 Aug Close & - & 2,489 & 5,050 & 100 & 30,525 & $25.3 \%$ \\
\hline 11 & 4 Sep Open & 2,296 & - & - & - & 30,525 & \\
\hline 12 & 14 Sep Close (Stop Loss) & - & 2,064 & $(5,800)$ & 100 & 24,625 & $-29.0 \%$ \\
\hline 13 & 2 Mor Open & 2,221 & - & - & - & 24,625 & \\
\hline 14 & 23 Mow Close & - & 2,490 & 6,950 & 100 & 37,475 & $34.8 \%$ \\
\hline
\end{tabular}

\section{PENUTUP}

Pergerakan harga FCPO selama 2006 sampai pertengahan 2008 cenderung naik, tetapi kemudia turun drastis sampai ke tingkat harga yang sama saat September 2006. Pertumbuhan harga FCPO tahun 2006 adalah yang terendah di bandingkan tahun 2007 dan 2008, hal ini membuat periode analisis data historis yang akan digunakan untuk menentukan model cyclic forecasting adalah periode 2007-2008. Model cyclic forecasting yang digunakan mengikuti pola siklus dua tahunan, sehingga akan terdapat 24 seasonal index dan 24 variabel dummy yang terlibat. Kombinasi fungsi Solver dalam Ms Excel dapat meminimalisasi MSE menjadi 161,02, dengan Beta 0,0688 dan intercept sebesar 11,0396. Sehubungan dengan trading policy, terdapat 4 kali transaksi yang menghasilkan gain, 2 kali transaksi yang menghasilkan loss dan 1 kali transaksi wait \& see, yang dapat menambah saldo awal simulasi dari RM 20.000 menjadi RM 31.475 atau ROM = 60,4\%.

\section{Saran}

Periode cyclic forecasting sebaiknya maksimum kurang dari setahun karena tingkat akurasi forecasting akan berkurang jika menggunakan periode yang lebih lama. Cyclic forecasting sebaiknya digunakan bersamaan dengan analisis teknikal, sekaligus analisis, sehingga calon investor perlu memonitor margin, agar mendukung trading strategy. Selalu gunakan stop loss untuk mengurangi risiko. Disarankan penggunaan stop loss tidak lebih dari setengah margin call. Diperlukan penelitian tambahan untuk menyesuaikan confidence level agar nilai VaR tidak terlalu besar, sehingga dapat memperbaiki keandalan trading strategy yang telah digunakan dalam penelitian ini. Pada perdagangan berjangka CPO di Malaysia, terdapat variasi besaran biaya atau fee yang ditawarkan oleh masingmasing broker house. Dalam prakteknya, investor dapat melakukan negosiasi biaya komisi broker. Biaya lain yang perlu diperhatikan adalah biaya akses real time platform untuk memonitor perkembangan bursa berjangka komoditas Malaysia, sebesar RM 200-500 per bulan. 


\section{DAFTAR PUSTAKA}

Aczel, A. D., \& Sounderpandian, J. (2002). Complete business statistic (5th ed.). New York: McGrawHill.

Barlow, J. F. (2005). Excel model for business and operation management (2nd ed.). Wiley \& Sons.

Colby, R. W. (2003). The encyclopedia of technical market indicators (2nd ed.). United States: McGraw-Hill.

Diebold, F. X. (2008). Element of forecasting (4th ed.). South Western, United States of America: Cengage Learning.

Elton, E. J., Gruber, M. J., Brown, S. J., \& Goetzmann, W. N. (2003). Modern portfolio theory and investment analysis (6th ed.). United States of America: John Wiley \& Sons.

Frenkel, M., Hommel, U., \& Rudolf, M. (2005). Risk management: Challenge and opportunity (2nd ed.). Germany: Spinger.

Hull, J. C. (2005). Fundamentals of futures and options markets (5th ed.). New Jersey: Pearson Education.

Holton, G. A. (2003). Value at risk: Theory and practice. USA: Academic Press Advanced Finance Series.

Katz, R. W., \& Murphy, A. H. (2005). Economic value of weather and climate forecasts. Cambridge University Press.

Schofield, N. C. (2007). Commodity derivatives: Markets and applications. Wiley Finance, John Wiley \& Sons. 